\title{
MASALAH DAN DINAMIKA IMPLEMENTASI KEBIJAKAN PUBLIK TENTANG TRANSPORTASI Kajian Di Kota Tasikmalaya, Jawa Barat
}

\author{
Awing Asmawi \\ Diah Fatma Sjoraida \\ Rully Khairul Anwar \\ Fakultas Ilmu Sosial dan Ilmu Politik \\ Universitas Padjadjaran, Bandung \\ email: awingasmawi@ymail.com
}

\begin{abstract}
ABSTRAK
Artikel ini membahas bagaimana kebijakan publik tentang transportasi dapat mempunyai masalah dan dinamika implementasinya di masyarakat. Kajian ini dilakukan di Tasikmalaya, Jawa Barat, Indonesia. Hal ini penting bagi masyarakat karena pembangunan layanan transportasi memiliki keterkaitan yang sangat erat dengan kesejahteraan sosial dan pertumbuhan ekonomi suatu wilayah. Hal tersebut dapat ditunjukkan dengan indikasi bahwa wilayah yang memiliki kelengkapan sistem transportasi yang berfungsi lebih baik dibandingkan dengan wilayah lainnya, maka wilayah tersebut cenderung mempunyai tingkat kesejahteraan sosial serta pertumbuhan ekonomi yang lebih baik pula. Sebaliknya, keberadaan transportasi yang kurang berfungsi dengan dengan baik akan mengakibatkan munculnya problem sosial dan masalah lingkungan. Kajian ini menggunakan metode kajian kasus berganda. Kasus-kasusnya terdiri dari kegiatan-kegiatan yang merupakan implementasi dari program sosialisasi pemerintah Kota Tasikmalaya kepada masyarakatnya mengenai transportasi. Wawancara, pengamatan, dan analisis dokumen digunakan untuk mengumpulkan data. Wawancara tatap muka memakai daftar pertanyaan telah dikembangkan untuk kajian ini. Temuan kajian menunjukkan bahwa selain merancang sendiri dan melaksanakan rencana pembangunan transportasi di dalam Kota Tasikmalaya itu sendiri maupun yang melibatkan pemerintah Provinsi Jawa Barat, bahkan pemerintahan nasional Indonesia.
\end{abstract}

Kata Kunci: Kebijakan Publik, Transportasi, Kota Tasikmalaya, Implementasi Kebijakan

\begin{abstract}
This article discusses how public policy on transport can have the issues and the dynamics of its implementation in society. The study was conducted in Tasikmalaya City, West Java, Indonesia. It is important to the society because the development of transport services has a very close relationship with social welfare and economic growth of a region. It can be shown with an indication that the region has a complete transportation system that works better than the other regions, then these regions tend to have a better level of social welfare and economic growth. Conversely, the presence of transport less functioning properly will result in the emergence of social and environmental problems. The study used a multiple case study method. The cases consist of activities in the implementation of Tasikmalaya city government outreach programs to the community regarding transport. Interviews, observation and document analyses were used to collect the data. Face-to-face interviews using a list of questions had been developed for this
\end{abstract}


study. The findings of the study indicate that in addition to designing their own and carry out the development plans of transport in Tasikmalaya City itself, there are also the plans involving the West Java provincial government, and even national government of Indonesia.

Keywords: Public Policy, Transport, Tasikmalaya City, Policy Implementation

\section{PENDAHULUAN}

Pengembangan layanan transportasi memiliki hubungan yang sangat dekat dengan kesejahteraan sosial dan pertumbuhan ekonomi suatu daerah. Hal ini dapat ditunjukkan dengan indikasi bahwa wilayah tersebut memiliki sistem transportasi lengkap yang bekerja lebih baik daripada daerah lain, dan kemudian daerah ini cenderung memiliki tingkat kesejahteraan sosial dan pertumbuhan ekonomi yang lebih baik pula. Sebaliknya, kondisi transportasi kurang berfungsi dengan baik akan mengakibatkan munculnya masalah sosial dan masalah lingkungan, sehingga kesejahteraan sosial dan pertumbuhan ekonomi akan terganggu.

Di beberapa daerah di Indonesia penyediaan layanan transportasi masih terkendala oleh terbatasnya jumlah alokasi anggaran. Ini disebabkan fakta bahwa sebagian besar dari anggaran itu dialokasikan untuk membiayai belanja pegawai di setiap daerah.

Kota Tasikmalaya telah ditetapkan sebagai Wilayah Pengembangan Priangan TimurPangandaran dalam Peraturan Daerah Provinsi Jawa Barat Nomor 22 Tahun 2010 tentang Rencana Tata
Ruang Wilayah Provinsi Jawa Barat Tahun 2009-2029. Jumlah penduduk kota ini pada tahun 2010 ialah 639.987 jiwa, sedangkan tahun 2015 sebesar 657.477 jiwa; yang dengan demikian mengalami peningkatan sebesar 17.490 jiwa dalam masa lima tahun. Hal ini menandakan bahwa Kota Tasikmalaya termasuk Kota yang mengalami perkembangan cukup signifikan. Selain menjadi daya tarik sebagai kota industri dan bisnis untuk priangan timur, Kota Tasikmalaya memiliki posisi yang sangat strategis dalam konstelasi wilayah di Jawa Barat, sehingga hal ini menjadi perhatian Pemerintah Provinsi Jawa Barat dalam upaya mengembangkan Priangan Timur dengan merencanakan pembangunan jalan tol dari Bandung sampai dengan Kota Banjar.

Dengan ditetapkannya Kota Tasikmalaya sebagai Pusat Wilayah Pengembangan Priangan TimurPangandaran respon yang dilakukan oleh Pemerintah Kota Tasikmalaya dengan merencanakan perkembangan kota dalam Peraturan Daerah Kota Tasikmalaya Nomor 4 Tahun 2012 tentang Rencana Tata Ruang Wilayah Kota Tasikmalaya Tahun 2011-2031 yang didalamnya 
berupa kebijakan Pemerintah Daerah dalam penataan ruang sesuai dengan Rencana Pembangunan Jangka Panjang Daerah (RPJPD) Kota Tasikmalaya pun disesuaikan dengan kondisi sosial masyarakat.

\section{TINJAUAN PUSTAKA}

Transportasi

ialah

seperangkat fasilitas berupa barang dan jasa yang disediakan untuk kepentingan publik atau masyarakat dalam pelayanan pemindahan. Transportasi memerlukan jasa atau fasilitas dasar dan peralatan yang dibutuhkan oleh masyarakat sebagai pelaksanaan fungsi suatu negara atau wilayah, misalnya penyediaan lahan, laut dan udara, dan pekerjaan umum sama-sama diperlukan dalam sistem transportasi (Srinivasu, 2013: 82).

Transportasi seperti yang diusulkan oleh Nasution (2004: 121) ialah transfer barang dan orang dari titik asal ke titik tujuan. Kegiatan tersebut berisi tiga hal: kargo untuk dikirim, ketersediaan kendaraan sebagai alat angkut, dan adanya jalan yang bisa dilalui. Ada proses bergerak dari tempat asal gerakan, dan kemudian ada transportasi dari awal dan tujuan di mana aktivitas tersebut terhenti. Oleh karena itu dengan pergerakan barang dan orang, transportasi merupakan salah satu sektor yang dapat mendukung kegiatan ekonomi (sektor mempromosikan) dan penyedia layanan (sektor servis) untuk pembangunan ekonomi. Sehingga transportasi ialah perilaku mengemudi orang dalam membawa dirinya sendiri dan membawa barang-barang.

Dengan demikian, baik atau buruk dari kondisi transportasi tergantung pada tiga faktor di atas. Ketiganya sangat penting dalam proses transportasi bahkan kecelakaan dan kemacetan dihasilkan dari tiga masalah ini. Tingkat transportasi dalam kecelakaan di jalan di kawasan Asia-Pasifik, yang meliputi Indonesia, menyumbang 44\% dari total kecelakaan di dunia. Kecelakaan lalu lintas juga mengakibatkan kemiskinan meningkat, karena kecelakaan lalu lintas yang menyebabkan biaya, hilangnya produktivitas, dan hilangnya pencari nafkah keluarga (Sari, 2012: 1).

Oleh karena itu, dalam Undang-Undang Nomor 22 Tahun 2009 tentang Lalu Lintas dan Angkutan, bahwa keselamatan berkendara merupakan prioritas mutlak, sebagaimana diamanatkan dalam Pasal 1, ayat 31 yang menjelaskan bahwa keselamatan lalu lintas dan angkutan jalan ialah keadaan orang menghindari semua risiko kecelakaan selama berlalu lintas yang disebabkan oleh manusia, kendaraan, jalan, dan / atau lingkungan (UU Lalu Lintas, 2009: 5). Sementara transportasi jalan diselenggarakan dengan tujuan menerapkan lalu lintas dan angkutan jalan dengan aman, lancar, tertib, nyaman dan efisien; mampu mengintegrasikan moda transportasi 
lainnya; menjangkau seluruh pelosok wilayah daratan, menunjang pemerataan, dan mendukung pembangunan nasional dengan biaya yang terjangkau oleh masyarakat (Kansil, 1995: 15).

Bahkan, sifat proyek pembangunan dilaksanakan oleh pemerintah dalam rangka meningkatkan kesejahteraan masyarakat. Demikian karena secara normatif, kesejahteraan masyarakat akan meningkat jika ada peningkatan nilai produk barang dan jasa yang dihasilkan oleh kegiatan pembangunan seperti proyek transportasi (Anwar, 2011: 52).

Transportasi yang baik membantu meningkatkan produktivitas dan menurunkan biaya dalam kegiatan ekonomi yang berlangsung. Pemenuhan transportasi yang memadai dapat membantu untuk meningkatkan produktivitas dan biaya langsung produksi yang lebih rendah, yang dapat lebih memperluas atau meningkatkan pertumbuhan (Gopalakrishna dan Leelavathi, 2011).

Transportasi mempengaruhi investasi dan pertumbuhan melalui peningkatan produktivitas dan efisiensi. Pengembangan transportasi akan meningkatkan keuntungan bagi perusahaan karena biaya produksi yang lebih rendah dan memperluas pasar. Dengan perluasan produksi, dampak pada pertumbuhan, pada gilirannya, akan mempengaruhi kesejahteraan (Srinivasu, 2013: 86).
Selain itu, menurut Ofyar Z. Tamin (2008: 68), infrastruktur transportasi memiliki dua peran utama, yaitu: (1) sebagai alat untuk mendorong pembangunan di daerah perkotaan dan (2) sebagai infrastruktur untuk pergerakan orang dan / atau barang yang timbul sebagai akibat dari kegiatan mereka di daerah perkotaan. Dengan melihat dua peran yang disebutkan di atas, peran pertama sering digunakan oleh pengembang perencanaan untuk mengembangkan wilayah wilayah mereka. Sebagai contoh, dalam perencanaan untuk mengembangkan wilayah baru tidak akan pernah ada permintaan jika wilayah tersebut tidak disediakan sistem infrastruktur transportasi. Dalam kondisi ini infrastruktur transportasi penting yang harus dibuat untuk aksesibilitas menuju daerah akan berdampak pada kepentingan publik yang tinggi untuk melakukan kegiatan ekonomi. Ini ialah penjelasan tentang peran infrastruktur transportasi, yaitu untuk mendukung pergerakan orang dan barang.

Kegiatan ekonomi dan transportasi memiliki hubungan yang sangat dekat, sehingga keduanya dapat mempengaruhi satu sama lain. Sebagai hasil dari pertumbuhan ekonomi, semakin banyaknya orang dan pergerakan dapat meningkatnya keperluan melebihi kapasitas infrastruktur transportasi yang tersedia. Dapat disimpulkan bahwa transportasi dan ekonomi memiliki ikatan yang kuat. Di satu sisi, 
transportasi dapat meningkatkan kegiatan ekonomi suatu daerah karena kehadiran infrastruktur transportasi daerah dapat meningkatkan kegiatan ekonomi mereka. Tapi di sisi lain, karena aktivitas yang tinggi di mana terdapat peningkatan pertumbuhan ekonomi, masalah yang timbul dari transportasi pun terjadi seperti kemacetan lalu lintas, sehingga muncullah keperluan untuk jalur transportasi tambahan (Tamin, 2008: 91).

Pentingnya sektor transportasi untuk kegiatan ekonomi membutuhkan sistem transportasi yang handal, efisien, dan efektif. Transportasi yang efektif berarti bahwa sistem transportasi memenuhi kapasitas angkut yang bersatu atau terintegrasi dengan moda transportasi lainnya secara tertib, teratur, lancar, cepat dan tepat, aman, nyaman dan ekonomis. Sementara efisien dalam arti beban publik sebagai pengguna jasa transportasi menjadi rendah dan memiliki kegunaan yang tinggi.

Klasifikasi transportasi dapat ditinjau pada empat unsur, yaitu jalan, peralatan transportasi, kekuatan pendorong, dan stasiun. Setiap elemen transportasi dapat dijelaskan sebagai berikut:

1) Jalan. Jalan merupakan keperluan yang paling penting dalam transportasi. Tanpa jalan tidak mungkin ada layanan transportasi bagi penggunanya. Jalan dimaksudkan dan disediakan sebagai dasar untuk sarana transportasi. Misalnya adalah jalan, kereta api, jalan air dan jalan udara.

2) Peralatan

Transportasi.

Kendaraan dan peralatan transportasi secara umum ialah elemen transportasi yang paling penting. Perkembangan dan kemajuan jalan dan peralatan transportasi ialah dua elemen yang saling membutuhkan atau saling terkait satu sama lain. Peralatan transportasi dapat dibagi menjadi jenis peralatan transportasi jalan darat, air atau udara. Peralatan transportasi jalan darat misalnya ialah: becak, gerobak, sepeda, sepeda motor, mobil, bus, truk, kereta api, dan lain-lain.

3) Kekuatan Pendorong. Yang dimaksud dengan kekuatan pendorong ialah kekuatan atau energi yang digunakan untuk menggerakkan alat transportasi. Untuk tujuan ini dapat digunakan tenaga manusia, tenaga hewan, uap, batubara, bahan bakar minyak, diesel, listrik, dll.

4) Terminal. Terminal ialah tempat di mana perjalanan transportasi dimulai atau berhenti atau berakhir sebagai tujuan. Karena itu di stasiun disediakan fasilitas pelayanan penumpang, bongkar muat dan penyimpanan barang. Untuk tujuan terminal itu, manusia menciptakan stasiun kereta api, stasiun bus, bandara, dan pelabuhan. 
Selain itu, transportasi dapat diklasifikasikan sebagai berikut:

1) Transportasi Darat. transportasi darat terdiri dari dua, yaitu:

a. Jalan raya. Ini termasuk transportasi menggunakan peralatan transportasi seperti manusia, hewan, gerobak sepeda, sepeda motor, becak, bus, truk, dan kendaraan lainnya.

b. Rail Road. Dalam peralatan transportasi kereta api itu digunakan dalam bentuk kereta api, terdiri dari lokomotif, gerbong, tank, kotak khusus, trailer dan kereta penumpang. Jalan yang digunakan dalam bentuk rel baja, baik dua rel atau monorel.

2) Transportasi Air. Transportasi melalui air dapat dibagi antara lain:

a. Transportasi air pedalaman. Yaitu penggunaan peralatan transportasi seperti rakit, perahu, boat, dan motor boat.

b. Transportasi laut.

Transportasi laut menggunakan alat seperti perahu transportasi, kapal uap, kapal, dll.

3) Transportasi Udara. Transportasi udara ialah sarana transportasi terbaru dan tercepat. Di sini, pesawat adalah sarana transportasinya dan udara atau angkasa sebagai jalannya. Pesawat ini dilengkapi dengan perangkat navigasi dan telekomunikasi.

Untuk memahami transportasi dalam kehidupan, diperlukan adanya organisasi. Menurut teori ketergantungan sumber daya ekonomi dan sosial, organisasi akan memiliki serangkaian hubungan dan akan terikat oleh hubungan lain atau dengan posisinya dalam sistem jaringan yang lebih luas. Organisasi biasanya tertanam dalam jaringan multi. Seringkali jaringan ini tumpang tindih satu sama lain. Perspektif kelas sosial dalam analisis jaringan sosial percaya pada argumen bahwa ekonomi, politik dan sosial di antara kelompok elite menciptakan kekuatan elit yang koheren (Mills, 1959). Sebuah perspektif ketergantungan sumber daya memandang organisasi sebagai aktor dan individu utama sebagai agen simbolik; sedangkan menurut perspektif kelas sosial, individu dipandang sebagai aktor utama dan organisasi sebagai kendaraannya. Jaringan antar-organisasi yang dibentuk dari kelompok ini merupakan sarana untuk memperkuat integrasi elite kekuasaan dan mempertahankan kontrol dari lembaga-lembaga utama sosial (Perry, 2002: 16). Di situlah gambaran pentingnya keterlibatan pemerintah di bidang transportasi, yaitu bagaimana pemerintah dapat mengontrol masalah transportasi ini. 


\section{METODE PENELITIAN}

Penelitian ini dilakukan dengan pendekatan kualitatif, yaitu dengan berfokus pada prinsip-prinsip umum fenomena sosial yang mendasar dalam masyarakat. Demikian karena objek analisis dalam pendekatan kualitatif ialah arti dari gejala sosial dan budaya dengan menggunakan budaya masyarakat yang bersangkutan untuk mendapatkan gambaran dari kategorisasi tertentu (Bungin, 2009: 302).

Sebagai pengayaan, penelitian ini didukung oleh metode jurnalisme, yaitu melalui proses pengumpulan, pemilihan, penulisan, editing, dan penerbitan berita (Weiner, 1990: 247). Penelitian ini menggunakan analisis isi sebagai salah satu metodologi untuk mengamati dan mengukur isi komunikasi (Flourney, 1992: 9). Analisis isi ini digunakan dalam melihat struktur dari berita tentang transportasi di Jawa Barat dan tempatnya dalam publikasi.

Metode komunikasi akan dikombinasikan dengan analisis wacana linguistik, karena komunikasi itu sendiri menggunakan bahasa sebagai kendaraan atau sebagai bahannya (Junus, 1996: 39). Karena analisis wacana digunakan oleh banyak aliran linguistik, akan berguna untuk mempelajari pers lokal dan nasional dengan menggunakan analisis semiotik yang "menetapkan bahwa analisis teks ialah bagian penting dari analisis sosial budaya media, dengan menghubungkan sifat teks dalam ideologi, hubungan kekuasaan dan nilai-nilai budaya" (Fairclough, 1995: 24). Pada gilirannya, perlu interpretasi bahasa untuk menyelidiki arti teks (Graber, 1989: 77; Junus, 1996: 39). Metode analisis wacana akan menjadi metode utama dalam penelitian ini untuk interpretasi simbol dalam bahasa seperti surat pembaca.

Singkatnya, isi penelitian akan mencakup berita, surat dan artikel. Berita terdiri sebagian besar kebijakan yang dibuat oleh para pemimpin politik, partai; berbagai pihak dipengaruhi oleh kebijakan pemerintah tersebut, dan reaksi mereka terhadap kebijakan tersebut. Umpan balik dari masyarakat umum juga membantu membawa penelitian ini ke arah "keterbukaan" dari apa yang laten. Artikel itu dirancang untuk meningkatkan dan menyelesaikan masalah melalui diskusi terbuka. Sedangkan editorial terdiri umpan balik dari media massa dan memainkan peranan besar dalam komunikasi politik. Dengan demikian, berita, surat, artikel dan editorial bersama-sama melakukan tugas komunikasi politik dalam masyarakat, termasuk dalam hal transportasi.

\section{OBJEK, HASIL PENELITIAN DAN PEMBAHASAN}

Dalam rangka untuk memenuhi kehidupan yang layak dari orang-orang dan pendatang di 
Kota Tasikmalaya, pemerintah telah merancang perencanaan pembangunan, termasuk di bidang transportasi. Ini melibatkan pemerintah daerah, pemerintah provinsi, dan pemerintah pusat. Rencana tersebut dilakukan melalui pengorganisasian, mengelola dan mengendalikan pasar yang mengganggu lalu lintas untuk diintegrasikan dengan kehadiran terminal dan fasilitas lainnya dan memukimkan kembali penduduk pasar yang tidak didukung oleh infrastruktur yang memadai.

Upaya-upaya tersebut di atas adalah dalam rangka mitigasi pemerintah Kota Tasikmalaya terhadap gejala-gejala sosial dan ekonomi yang ditimbulkan dari problem-problem transportasi. Demikian itu dilakukan agar cita-cita tata ruang wilayah dapat tersampaikan kepada masyarakat, sehingga masyarakat pun memahami dan memakluminya apabila pihak pemerintah menjalankan programprogram pembangunan. Sebab kota yang maju umumnya memiliki aturan mengenai tata ruang dalam mengatur wilayahnya. Misalnya, ada wilayah menjadi daerah pusat kota (Central Business District), daerah penyangga (Buffer Area), daerah permukiman (Settlement Area), daerah industri (Industry Area) atau daerah pertanian (Farming Area) sehingga jika diperhatikan maka akan terlihat bagaimana sebuah kota yang tertata dengan baik.

\begin{abstract}
Konsekuensi penerapan aturan mengenai tata ruang ialah adanya factor $\quad x$ (jarak), factor $c$ (biaya) dan rent (sewa), ketiga factor tersebut saling mempengaruhi satu sama lainnya sebagaimana yang telah dijelaskan oleh William Alonso (dalam Yunus, 2000:77) membahas tentang teori bid-rent analysis (sewa tanah), dimana penyebaran keruangan kegiatan industri berlokasi diantara perumahan dan retail. Semakin dekat dengan pusat kota (pusat bisnis) maka harga (sewa) tanah semakin tinggi, begitu juga sebaliknya. Dengan kata lain, sewa yang ditawarkan orang untuk membayar tanah per meter perseginya, menurun mengikuti jaraknya dari pusat kota (komersial/bisnis).

Pusat kegiatan masyarakat
\end{abstract} Kota Tasikmalaya berada sepanjang koridor H. Zaenal Mustafa, Jalan Cihideung, Jalan Pasar Wetan, Jalan Dr. Soekardjo, Jalan Sutisna Senjaya, Jalan Pataruman yang merupakan satu blok yang dalam Rencana Tata Ruang Wilayah (RTRW) Kota Tasikmalaya sebagai Central Business District (CBD) yang berfungsi sebagai Pusat Pelayanan Kota (PPK) yang melayani regional wilayah di sekitarnya. Dampak yang ditimbulkan akibat dari pusat pelayan ialah lalu lintas, pusat pedagang kaki lima, pusat hunian sementara, penyerapan tenaga kerja dan lain-lain yang menyebabkan beban dari wilayah tersebut menjadi overload sehingga 
pelayanan terhadap masyarakat kurang optimal.

Upaya Pemerintah Kota Tasikmalaya dalam membangun wilayahnya terus dilakukan dengan berbagai cara, diantaranya dengan mengatur sistem transportasi, baik yang bersifat antar wilayah atau luar wilayah. Tercatat sampai dengan akhir tahun 2015, terdapat 21 trayek angkutan kota yang melayani hampir seluruh wilayah kota dan 3 rencana trayek baru guna membuka akses ke lokasi yang belum tersentuh oleh angkutan umum.

Selain upaya pengaturan sistem transportasi, Pemerintah Kota Tasikmalaya melakukan pembangunan jalan lingkar yang berfungsi untuk mengurai titik-titik kemacetan baik yang menghubungkan wilayah TimurBarat maupun Utara-Selatan yang saat ini pada jam tertentu (rush hour) sering menjadi simpul kemacetan. Oleh karena itu, kebijakan membangun jalan lingkar luar Kota Tasikmalaya merupakan solusi yang jitu.

Sampai akhir tahun 2015,
ruas jalan Mangkubumi $\begin{array}{r}\text { dan } \\ \text { dapat }\end{array}$
Indihiang sudah
dioperasionalkan dengan normal,
walaupun masih perlu banyak
penyempurnaan seperti ketersediaan
marka jalan dan kelengkapan jalan
lainnya. Pada tahun 2017 ini
pembangunan ruas 1 lingkar luar
Utara akan mulai dilaksanakan yang
mengambil titik awal Pos AU sampai
dengan Karang Resik yang

pembebasan lahannya telah dilaksanakan pada tahun 2015. Diharapkan akhir tahun 2017, ruas lingkar utara tahap 1 Pos AU-Karang Resik dapat beroperasi sehingga membuka akses Utara-Timur yang menghubungkan antara wilayah Manonjaya-Ciamis. Selanjutnya diharapkan ruas lingkar utara tahap 2 Karang Resik-Letjen Ibrahim Adjie dan lingkar selatan A.H. NasutionPerintis Kemerdekaan dapat dilaksanakan sehingga akhir perencanaan tata ruang Tahun 2031 jalan lingkar di Kota Tasikmalaya sudah terhubung.

Dari segi kendaraan, pada awal tahun 2000-an ialah perkembangan jumlah kendaraan yang cukup melonjak dengan kemudahan untuk memiliki kendaraan tidak diiringi dengan meningkatnya kapasitas jalan atau penambahan jalan baru, sehingga akibatnya muncul titik-titik kemacetan. Selain itu, ketidakmampuan pemerintah untuk menciptakan moda transportasi masal, aman, dan nyaman merupakan faktor utama yang mendorong masyarakat untuk memiliki kendaraan.

Berkaca dari pengalaman Jakarta, bukan tidak mungkin Kota Tasikmalaya yang pada saat ini dikategorikan sebagai kota besar (mengacu kepada jumlah penduduk antara $500.000-1.000 .000$ jiwa) akan berkembang menjadi salah satu kota yang menjadi pusat pertumbuhan di priangan timur atau 
bahkan Jawa Barat sesuai dengan visi "Dengan Iman dan Takwa Kota Tasikmalaya sebagai Pusat Bisnisdan Industri Termaju di Jawa Barat" maka hal-hal yang menyangkut dengan sistem transportasi masal perlu benar-benar direncanakan dengan sebaik-baiknya.

Perlu dipahami, bahwa Pemerintah Daerah berkewajiban untuk dapat melayani masyarakatnya dalam hal ini menyediakan moda transportasi yang baik, nyaman dan ramah lingkungan. Konsep yang cocok diterapkan untuk di Kota Tasikmalaya ialah mengembangkan moda transportasi masal yang bersifat komuter (Commuter) artinya menyediakan sistem transportasi yang terkoneksi dengan angkutan kota bagi pekerja yang berasal dari luar pusat kota dengan menyediakan beberapa pemberhentian (shelter) sebagai tempat koneksi dengan angkutan umum. Sehingga masyarakat akan dengan mudah menuju lokasi yang dituju tanpa harus membawa kendaraan pribadi.

Adapun konsep komuter ini sangat sederhana dan tidak banyak mengeluarkan biaya yang cukup besar, yaitu dengan memanfaatkan ketepatan waktu dan tarip yang terjangkau oleh masyarakat dengan sistem flat. Artinya waktu keberangkatan untuk masing-masing armada sudah diatur berdasarkan kajian yang dibuat, apakah dengan selang waktu 15 menit, 20 menit atau 30. Sehingga masyarakat akan lebih mengetahui dengan pasti kapan armada tersebut ada pada tiap shelternya.

Sebagai gambaran jarak total jalan lingkar Kota Tasikmalaya ialah $\pm 34,2 \mathrm{~km}$ dengan jumlah shelter 18 unit sesuai dengan jumlah persimpangan dan tempat strategis lainnya. Waktu tempuh tiap-tiap armada dengan kecepatan rata-rata $40 \mathrm{~km}$ per jam dan untuk tiap-tiap shelter maksimal berhenti 1 menit, dengan 18 shelter maka akan menghabiskan waktu 18 menit, sehingga jarak tempuh untuk kembali ke tempat awal \pm 1 jam .

Berikut ilustrasi untuk masing-masing ruas dengan jumlah shelter pemberhentiannya.

1) Mulai Terminal Indhiang - AH. Nasution $(7,7 \mathrm{~km})$. Rute ini dibuat sebagai salah satu upaya untuk mengoptimalkan lahan terminal yang belum efektif dan efisien, artinya jika armada bus trans tasik yang memanfaatkan terminal sebagai tempat pemberhentian awal dan akhir maka sistem angkutan di Tasikmalaya akan terintegrasi dengan baik, dengan kata lain, penumpang bus dari terminal Indihiang akan bisa langsung menggunakan moda lain untuk menuju tujuan akhir.

2) Nasution-Perintis Kemerdekaan $(8,6 \mathrm{Km})$. Untuk ruas ini, merupakan penghubung antara wilayah barat dengan wilayah selatan Kota Tasikmalaya atau dikenal dengan Lingkar Selatan, mulai dari shelter AH. Nasution 
- Cibeuti - Perintis

Kemerdekaan.

3) Perintis Kemerdekaan-Pos AU $(6,4 \mathrm{Km})$. Ruas ini meruupakan ruas yang sudah ada, yaitu jalan Mashudi yang menghubungkan antara persimpangan perintis kemerdekaan dengan pos AU (Rencana Bandara Komersil Kota Tasikmalaya).

4) Pos AU-Terminal Indihiang $(9,5$ $\mathrm{Km})$. Dan ruas terakhir merupakan ruas yang menghubungkan antara Pos AU dengan Terminal Indhiang atau disebut dengan lingkar utara, ini merupakan ruas yang menghubungkan antara Bandara dengan Terminal.

Untuk dapat dengan pasti dan tepat dalam menentukan moda transportasi dan sistem yang dilakukan maka diperlukan kajian lebih lanjut baik dari aspek social kemasyarakatan, cost- benefit, kebijakan dan lain sebagainya.

Pembukaan akses jalan, konstruksi jalan raya dan rekonstruksi jalan membuat pergerakan orang dan barang lebih lancar sehingga akan menggerakkan perekonomian lebih cepat dan secara tidak langsung akan meningkatkan pendapatan. Seiring dengan meningkatnya pendapatan, pendapatan ke daerah harus ditingkatkan karena pembangunan infrastruktur yang baik membutuhkan biaya tinggi.

Aspek lain dari kebijakan transportasi di Kota Tasikmalaya ialah salah satu budaya. Mengacu pada tujuh unsur kebudayaan yang bahasa, sistem mata pencaharian, teknologi, agama, seni dan pengetahuan sistem semua bergeser dan reorientasi. Terjadinya mobilitas tinggi membuat orang terbuka untuk hal-hal baru dan sensitif terhadap informasi dan teknologi.

Begitu pula dengan seni. Kebijakan transportasi dapat juga berupa seni seperti adanya jalan layang di Kota Bandung yang mendapatkan respon positif dari masyarakat. Program seperti ini akan berjalan dengan baik di kota Tasikmalaya.

Dengan demikian, kebijakan sosiologis transportasi telah mengangkat tiga interaksi interaksi bisnis, interaksi politik dan interaksi budaya. Interaksi bisnis ialah titik interaksi kegiatan ekonomi sebagai dasar dan langkah-langkah yang digunakannya sangat ekonomis. Interaksi politik ialah interaksi yang dapat menciptakan ketergantungan dari kelompok ke kelompok lain. Interaksi budaya ialah bentuk hubungan sosial di mana budaya menjadi modal mereka. Dalam interaksi budaya mungkin terjadi pertemuan antara dua atau lebih individu pendukung untuk unsurunsur budaya yang berbeda. Pertemuan ini menghasilkan perhubungan satu sama lain, saling mempengaruhi dan memperkuat satu sama lain sampai membentuk budaya baru. 
Ada beberapa langkah pola komunikasi kebijakan transportasi di Kota Tasikmalaya, yaitu:

1) Melalui jalur media konvensional, seperti media cetak atau media elektronik.

2) Melalui komunikasi formal, yaitu para pekerja pemerintah dari atas ke bawah.

3) Melalui komunikasi tradisional, yaitu pemerintah mendekati masyarakat dan pemimpin informal, seperti pemimpin organisasi masyarakat, pemimpin tradisi, dsb.

4) Melalui http://www.tasikmalayakota.go.i d/ situs di mana ada sebuah portal terbuka bagi orang untuk berkomunikasi secara langsung dengan pemerintah.

5) Melalui saluran komunikasi pribadi seperti telepon, layanan pesan singkat (sms), dll.

6) Melalui jalur media sosial seperti Facebook, WhatsApp, dll.

\section{KESIMPULAN}

Berdasarkan uraian dan penjelasan di atas, dari penelitian ini dapat ditarik kesimpulan sebagai berikut:

1. Apa yang datang ke permukaan, melalui media massa, masyarakat kota Tasikmalaya sebagian besar menyambut kebijakan yang mendukung transportasi yang mudah, aman, nyaman dan terjangkau. Dengan demikian, pengembangan kebijakan transportasi telah dikomunikasikan dengan baik oleh pelaksana kebijakan.

2. Dengan kemajuan transportasi, baik darat, laut atau udara; telah terjadi perubahan sosial, budaya, dan bahkan teknologi masyarakat.

3. Sosial, kebijakan transportasi di kota Tasikmalaya telah mengakibatkan lebih massifnya interaksi bisnis, politik, dan interaksi budaya.

4. Selain kebijakan ekonomi, sosial, budaya, dan teknologi, transportasi pun dapat menambah rasa seni masyarakat.

5. Kebijakan Transportasi di kota Tasikmalaya ialah sistemik, di mana perubahan satu hal akan mengakibatkan hal-hal lain.

6. Sudah terdapat ide-ide penambahan fasilitas jalan dan moda transportasi pada pemerintahan Kota Tasikmalaya.

6. Komunikasi dari kebijakan transportasi dilakukan oleh pemerintah melalui berbagai cara, yaitu media konvensional, formal, website, komunikasi tradisional, komunikasi pribadi, dan media sosial.

\section{DAFTAR PUSTAKA}

Bungin, Burhan. (2006). Sosiologi Komunikasi: Teori, Paradigma, dan Diskursus Teknologi Komunikasi di Masyarakat. Jakarta: Kencana. Ali, Muhidin S. dan Abdurrahman, M. 2007. Analisis Korelasi, Regresi dan Jalur dalam 
Penelitian. Bandung: CV. Pustaka Setia.

Anwar, Nurul. 2011. Evaluasi Proyek-Proyek Pembangunan Pemerintah, Purwokerto: Percetakan dan Penerbitan UNSOED.

Badan Pusat Statistik (BPS). 2014. Jawa Barat Dalam Angka (Tahun 2008-2013). Bandung: Bappeda Jawa Barat dan Badan Pusat Statistik Propinsi Jawa Barat.

Budiardjo, Miriam. 1985. Aneka Pemikiran Tentang Kekuasaan dan Wibawa. Jakarta: Sinar Harapan.

Deutsch, Karl W. 1986. "The Crisis of State, Government and Opposition" dalam Roy C. Micridis, "Comparative Politics" dalam A.R. Henry Sitanggang, (terj.) Perbandingan Politik, Jakarta: Erlangga.

Dunn, William N. 2003. Pengantar Analisis Kebijakan Publik. Yogyakarta: Gadjah Mada University Press.

Fairclough, Norman. 1995. Media Discourse, New York: Arnold, 1995.

Flourney, Don Michael (ed.). 1992.

Content Analysis of

Indonesian Newspapers,

Yogyakarta: Gadjah Mada University Press.

Gopalakrishna and Leelavathi, D.S. 2011. " Infrastructure and Human development in India: An Inter-state comparison.
Journal of Global Economy (ISSN 0975-3931), Volume 7 No 4, October-December, 2011.

Graber, Doris A. 1989. Mass Media and American Politics, Washington, D.C.: CQ Press.

http:// bisnis news.viva.co.id/ news/read/464409 ini provinsi peraih penghargaan pemeliharaan jalan terbaik.

http://dispenda.jabarprov.go.id/2016/ 05/28/pad-dan-peningkataninfrastruktur-di-jawa-barat/. http://ekonomi kompasiana.com/ bisnis/ 2013 / 05/22/itf 2013 mengupas-peran dan pembiayaan transportasi 562271.html.

Jabarprov.go.id. 2014. Panjang Jalan Menurut Kondisi Jalan dan Tingkat

Kewenangan.http://perwakilan .jabarprov.go.id/artikel/datajab $\operatorname{ar} / 25$.

Junus, Umar. 1996. Teori Moden Sastera dan Permasalahan Sastera Melayu, Kuala Lumpur: Dewan Bahasa dan Pustaka.

Kuncoro, Mudrajad. 2006. Ekonomika Pembangunan: Teori, Masalah, dan Kebijakan. Edisi Keempat. Jakarta: UPP STIM YKPN.

Magnis-Suseno, Franz. 1995. Filsafat sebagai Ilmu Kritis. Kanisius: Yogyakarta.

Mahathir, Muhamad. 2011. "Konsep Kesejahteraan".

http://mahathir71.blogspot.co 
m /2011/12/konsep-

kesejahteraan_16.html.

Nee, Victor. 2005. The New

Institutionalism in Economics and Sociology. Center for economy and Society,Ithaca: Cornell University.

Poerwadarminta, W.J.S. 1984.

Kamus Umum Bahasa

Indonesia. Jakarta: Balai

Pustaka.

Somashekar, Ne. Thi. 2003.

Development and

Environmental Economics,

New Age International

Publishers.

Srinivasu, B. 2013. Infrastructure of Development and Economic

Growth: Prospects and Perspective. Dalam Journal of
Business Management \& Social Sciences Research (JBM\&SSR). ISSN No: 23195614 Volume 2.

Sunggono, Bambang. 1994. Hukum dan Kebijakan Publik. Jakarta: Sinar Grafika.

Wahab, Solichin Abdul. 2008. Analisis Kebijaksanaan: Dari Formulasi ke Implementasi Kebijaksanaan Negara. Jakarta: Sinar Grafika.

Weiner, Richard. 1990. Dictionary of Media and Communications, New York: Simon \& Schusters.

www.bps.go.id., 2016.

www.id.wikipedia.org.

www.jabar.bps.go.id.,

2016. 